\title{
The Influence of Commercial Development by Quasi-Public Agencies on the Urban Spatial Pattern of Pathumwan District, Bangkok, Thailand
}

\author{
Nicha Tantivess ${ }^{1}$, David J. Edelman ${ }^{2}$ \\ ${ }^{1}$ Faculty of Architecture, Khon Kean University, Khon Kaen, Thailand \\ ${ }^{2}$ School of Planning, University of Cincinnati, Cincinnati, Ohio, USA \\ Email: ntantivess@gmail.com, edelmadj@ucmail.uc.edu
}

How to cite this paper: Tantivess, N., \& Edelman, D. J. (2021). The Influence of Commercial Development by Quasi-Public Agencies on the Urban Spatial Pattern of Pathumwan District, Bangkok, Thailand. Current Urban Studies, 9, 159-180. https://doi.org/10.4236/cus.2021.92010

Received: March 13, 2021

Accepted: April 18, 2021

Published: April 21, 2021

Copyright $\odot 2021$ by author(s) and Scientific Research Publishing Inc. This work is licensed under the Creative Commons Attribution International License (CC BY 4.0).

http://creativecommons.org/licenses/by/4.0/ (c) (i) Open Access

\begin{abstract}
This paper defines the urban spatial pattern of the Pathumwan District in Bangkok after the end of the period of Thai absolute monarchy in 1932, although the monarchy still maintained important influence in the area. The district is known as a prime commercial zone of the capital city where Siam BTS Station, one of the busiest Bangkok mass transit hubs, is located. Unlike other commercial areas in Bangkok, the district represents images of a modern city with traces of royal traditional elements in the period of Thai absolute monarchy. The research data were collected from archival materials including official documents, newspapers, magazines, and other related publications. The results show that the Crown Property Bureau (CPB) and Chulalongkorn University, two large and powerful quasi-public agencies, are the major influential landlords whose properties absorb a huge amount of investment, as well as generate commercial clusters, with intense commercial competition among business groups, along the corridor of Rama I-Sukhumvit Road. Investors try to sustain their clusters, but those with less economic strength are forced to leave the area.
\end{abstract}

\section{Keywords}

Post-Thai-Absolute-Monarchy, Quasi-Public Agency, The Crown Property Bureau (CPB), Chulalongkorn University, Pathumwan District, Bangkok

\section{Introduction}

Pathumwan was originally a part of Bang Kapi Field (also known as the Saen Saep 
Field), a large marshland suitable for rice farming with small communities of different ethnic groups such as the Lao, Malay, and Cham (Tourism Division, Culture, Sports and Tourism Department, BMA, 2011: pp. 129-140). The physical boundary of Pathumwan was defined by the Saen Seap, Pai Singto, Hua Lumphong, and Padung Krungkasem Canals (Bangkok Municipal Ministry, 1902-1903: p. 49; Bunnag, 1982: pp. 89-99). Figure 1 shows the general map of Pathumwan District between 1997 and 2018.

The history of real estate development in the Pathumwan District can be traced back to the reign of King Rama IV (1851-1868) who built Srapathum Palace and Pathumwanaram Temple as a place to spend his vacations during the rainy season (October through December) in the area of the royal rice paddy of Pathumwan. More plots of land were also purchased from local residents in order to expand the palace area (Pathumwanaram Temple, 1977: pp. 9-17). These two constructions were also considered the first royal landmarks of the area. Thereafter, Pathumwan Road (later known as Rama I Road) was constructed to facilitate the King's trip to his vacation palace (Preyawanit, 2017, pp: 130-131).

During the reign of King Rama V (1868-1910), Pathumwan became the secondary administrative center of the Siamese government interspersed with an extended area of Siamese-noble and foreign residents (Tantivess, 2020: pp. 176-179). Moreover, the interspersed zone is considered one of the important elements that help to define the distinct urban pattern of the semi-colonial city from other colonial cities in Southeast Asia.

\section{Differences between Bangkok as a Semi-Colonial City and Other Colonial Cities in Southeast Asian}

Colonialism was an exogenous influence that modernized Southeast Asian traditional urban societies through four different modes: education, administration, economy, and community control. To monopolize the production system of the whole state, Western colonizers tried to reduce the power of the indigenous ruler by diminishing the traditional feudal system of the state. The capitalist economy was introduced to Southeast Asian society. By means of land commodification policy and developing infrastructure systems, all lands and resources in the colonial states were put into the production system. Meanwhile, local people with Western education were freed from the old feudal system and were also prepared to be a labor force. Furthermore, the colonizers proclaimed an ethnic segregation policy and changed the status of the local leaders to disrupt business competition from the local level (O'Connor, 1983: pp. 70-76).

Although Siam, as Thailand was formerly known, was never colonized, colonial influence in Southeast Asia extended to this kingdom. Hence it is status as a semi-colonial city. Siamese society was gradually dominated by the capitalist economy through the Bowring Treaty, which was signed in 1855. However, unlike in the colonial cities, most of the economic power was still monopolized by Siamese elites led by the King, who were able to adapt themselves to the new 


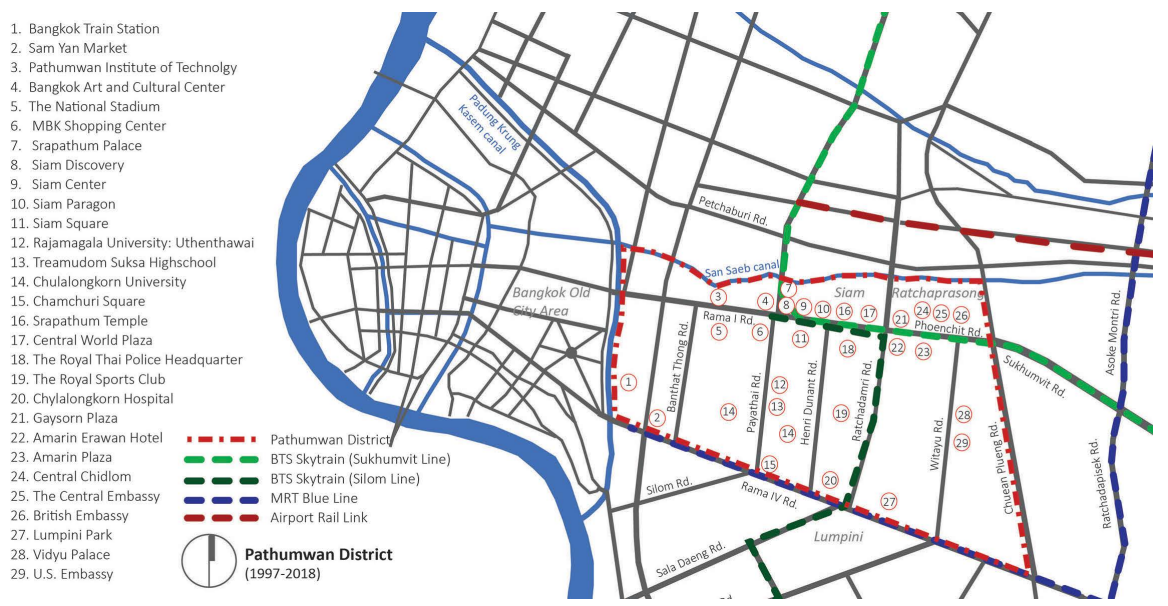

Figure 1. Map of Pathumwan district (created by the authors).

economy (Sritulpan, 2006 [1957]: pp. 263-275). Meanwhile, the Siamese King tried to strengthen his administrative power in order to take control of all agricultural production in the kingdom by applying the British colonization model. Aside from reducing the power of the aristocracy and changing the status of former independent provincial governors to that of government officers, the King also developed infrastructure systems, especially the transportation routes (such as canals, roads, and railways) to create better access from the capital city to other provinces (Askew, 2002: pp. 23-32). Moreover, unlike other Southeast Asian colonial states, the Siamese King did not attempt to change the kingdom into another modern-Westernized country, but rather to establish the image of Siamese elite prestige (Jackson, 2010: pp. 194-197).

The physical changes in Bangkok also portrayed Pathumwan as a transitional area between the inner-city and provincial areas. Saen Seap Canal, which was originally considered the only major transportation route in the area, was widened and extended, while several new canals were also dredged along with the process of land commodification (Bangkok Municipal Ministry, 1907a: pp. 192-193; Bunnag, 1982: pp. 45-48). The origin station of Pak Nam Railway, the first rail route in Siam that connected the capital city to Samutprakarn, was also located in Pathumwan (Bangkok Municipal Ministry, 1907b: pp. 2-22; Bangkok Municipal Ministry, 1911: pp. 9-16). Meanwhile, the road network was gradually expanded into the district as a result of the expansion of public services and settlements from the inner-city area toward the east and also to the south where foreign quarters were located (Preyawanit, 2017: pp. 140-142).

According to Evers and Korff, typical Southeast Asian colonial cities can be categorized into three patterns: the sacred city was the religious and administrative center of the indigenous ruler, the commercial city was the trading center that later became the administrative center of the Western colonizers, and the intermediate city was the location of local communities and also the prime agricultural production area. The sacred city continuously lost its importance to the commercial city, including the power to control agricultural production in the 
area of the intermediate city (Figure 2). After the end of the colonial period, these colonial cities were transformed into primate cities, large urban areas that are a concentration of administrative and economic power. Moreover, these cities also became foreign to the overall Southeast Asian cultural context (Evers \& Korff, 2000: pp. 29-34).

Unlike the urban pattern that is explained above, the urban pattern of Bangkok as a semi-colonial city shows an overlapping of activity flows from the inner-city area (the sacred city) and foreign quarters along the Chao Praya River (the commercial city) at Pathumwan District, where palaces, public facilities, educational institutions, embassies, recreational parks, and Western-style settlements were located (Figure 3). Furthermore, this interspersed zone continuously expanded its area into the nearby rural community zone via infrastructure development (Tantivess, 2020: pp. 464-465).

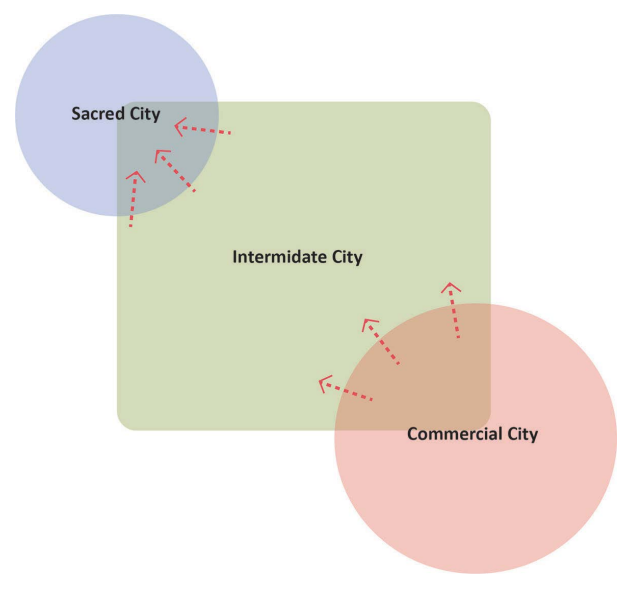

Figure 2. Urban pattern of southeast Asian colonial cities (created by the authors).

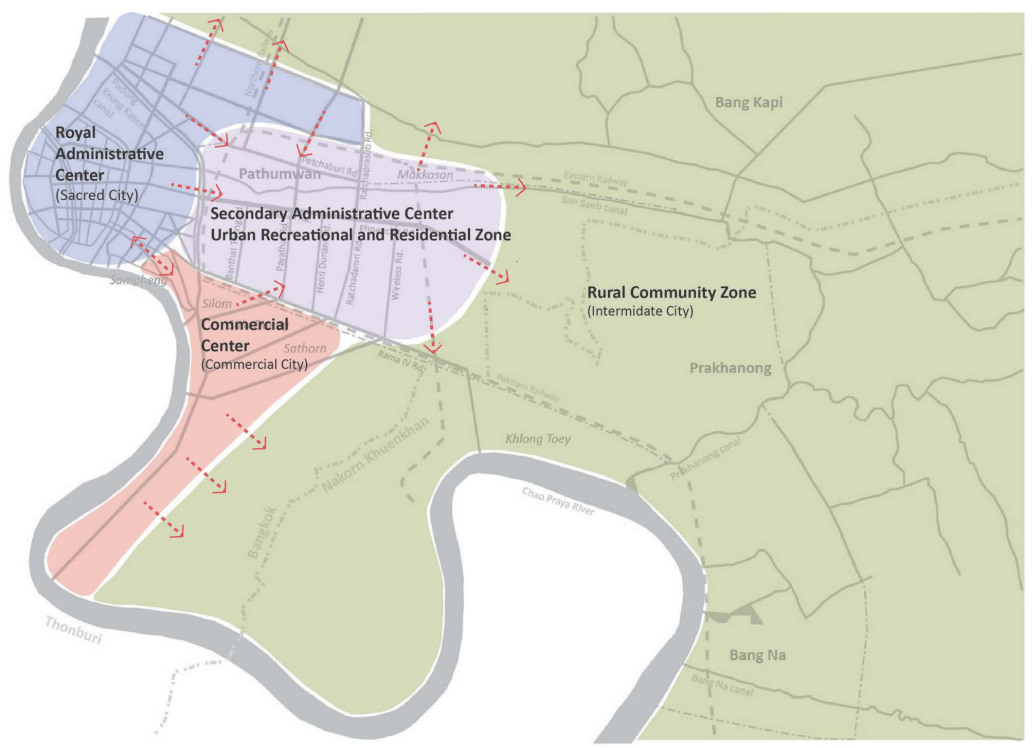

Figure 3. Urban pattern of Bangkok as a semi-colonial city (created by the authors). 
However, an understanding of the urban form of Bangkok in the later period is not only derived from its status as a semi-colonial city because the city is generally considered as one of the Southeast Asian primate cities, which are determined by the influence of the global economy (McGee \& Robinson, 1995: pp. 343-355). These cities become an attractive location for foreign investment because of cheap labor and adequate resources for production, and their economy still depended on foreign financial aid (Douglass, 2001: pp. 33-56). Moreover, the cities faced uneven development in which public services were unequally distributed, while the urban settlements also rapidly expanded because they absorbed a huge number of migrants from rural areas (McGee, 1967: pp. 186-198). However, the urban pattern of Bangkok after the end of the absolute monarchy period in 1932 is different from other Southeast Asian post-colonial cities in the same period; and examining the transformation of the Pathumwan District helps to define a distinct urban pattern of this post-semi-colonial city.

\section{Discussion of the Rise and Importance of Quasi-Public Agencies in Pathumwan District's Commercial Development and Spatial Transformation}

\subsection{Transferring Right of Land Possession to the New Agencies}

After the Siamese Revolution in 1932, the power of the Thai royal family, as well as their property recession rights, was restricted. According to the report of the parliamentary meeting on March 29, 1936, the then government attempted to change royal properties, especially those that were used for commercial purposes, into assets for the public interest. Operating all royal assets during the period of Siamese absolute monarchy, the Privy Purse Bureau (PPB), an organization within the Ministry of Finance, therefore had its role reduced and was placed under the Office of the Prime Minister (King, 2011: pp. 90-91).

Furthermore, the royal assets were categorized into two types: private and public royal properties. The private royal properties referred to the personal assets of royal family members. Most of them were palaces and residences, and they were managed by the Bureau of the Royal Household (BRH). Meanwhile, the royal public properties were used for business or public purposes (Thai House of Representatives, 1936). Afterward, the Crown Property Bureau (CPB) was established in 1937 to replace the PPB and operate these royal public properties (Baker \& Phongpaichit, 2005: pp. 116-121). The CPB was administered by a nine-person committee, whose members were selected by the parliament from representatives of the royal family, Thai nobles and the democratic government. Meanwhile, the Minister of Finance has appointed the chair of the committee (Announcement of the Office of the Prime Minister about the Appointment of the Crown Property Bureau's Committee, 1937a: p. 739; Announcement of the Office of the Prime Minister about the Appointment of the Crown Property Bureau's Committee, 1937b: p. 2480). 
One of the transferred properties was the campus of Chulalongkorn University, the first university in Thailand, which was founded by King Rama VI in 1910. The university was located on a PPB-owned large plot of land in Pathumwan District. Moreover, the university was allowed to use the property for commercial purposes in order to make the university less financially dependent on the central government budget, and this business income could also be used for subsidizing all of the annual property rent to the PPB (Chulalongkorn University, 2017: pp. 48-65). The properties of Chulalongkorn University were directed by the CPB until 1939 when they were completely transferred to the university (Property Alienation Act about Transferring Land of the Crown Property Bureau to Chulalongkorn University, 1939). By 1941, the university reallocated Chulalongkorn Hospital to be an asset of the Thai Red Cross Foundation (Property Alienation Act about Transferring Land in Pathumwan District between Pai Sing to Canal, Ratchadamri and Sanam Ma Roads to The Red Cross Society, 1942).

Both CPB and Chulalongkorn University remained public organizations until the 1940s, when they became quasi-public agencies regarding their status as juristic entities. They also became influential business actors in Pathumwan District in the late 1950s. In 1934, the Chulalongkorn University Act was adopted to define the university's status as a juristic entity. Therefore, the responsibility for managing all the university's properties was transferred to the Secretary's Office in 1935 in order to prepare the property transfers from the CPB in the next four years (Chulalongkorn University, 2017: p. 67). In 1948, the new Crown Property Act was also revised to change the status of the $\mathrm{CPB}$ as a juristic person that was independent from government control. Moreover, the King received full authority to choose the director and the board members, although the Minister of Finance remained the chairperson of the committee (Ouyyanont, 2015: p. 18).

The above explanation shows that the restriction of the property possession right of the royal family after the revolution was imposed only temporarily. Although the properties were already transferred to different agencies, the monarch was still able to regain his right over the majority of the royal properties through the CPB administrative members he chose. Meanwhile, Chulalongkorn University, which was completely free from the control of both government and the monarch, still represented itself as a legacy of the Siamese King to the Thai citizens.

\subsection{Urban Physical Changes and Business Opportunities}

Once property rights were transferred to $\mathrm{CPB}$ and Chulalongkorn University, the business potential in Pathumwan District started to evolve along with the development of the transportation system in eastern Bangkok. Originally, the district was only considered a suburban zone due to limited road accessibility. Although traveling by Pak Nam Train to Samutprakarn would take only two to three hours, only high-income people could afford the rail fares (Bangkok Mu- 
nicipal Ministry, 1907b: p. 2-22; Bangkok Municipal Ministry, 1911: pp. 9-16). Furthermore, the canal network in the area was gradually becoming ineffective because of severe droughts between 1896 and 1905 (Bangkok Municipal Ministry, 1897: p. 650), while the urban residential zone continuously expanded from the inner-city area (“The Map of Bangkok", 1871: pp. 146-157).

Although the construction of Sukhumvit Road (which was another effectively connected path between the areas of eastern Bangkok and Samutprakarn) was completed in 1936, commercial activities were not yet very pronounced because of political instability after the 1932 revolution, and the Second World War that slowed the urban development process of Bangkok. However, commercial developments in the district had two major cycles of rapid growth regarding two large urban physical developments: 1) during the 1970s via transportation development according to The Greater Bangkok Plan 2533; and 2) since the 2000s by the development of the mass-transit systems in Bangkok.

\subsubsection{Commercial Growth during the 1970s via Transportation Development According to the Greater Bangkok Plan 2533}

Urban physical changes in Pathumwan District started to emerge distinctively in the 1970s as a result of the administration of Field Marshall Sarit Thanarat (1957-1963), which aimed to industrialize the country. Thailand also received support from the United States through the United States Operation Mission (USOM) to develop its economy and infrastructure, while Thailand became an important U.S. military base during the Vietnam War (1955-1975) (Bangkok Bank, 1973: p. 8). This support also included the elaboration of the first urban comprehensive plan of Bangkok, The Greater Bangkok Plan 2533, which identified Pathumwan District in 1990 as a commercial zone extension as a result of the growth of commercial activities from Silom, the business center of Bangkok ("Nakonluang Wanprungnee [A City of Tomorrow]", 1972: p. 10). Moreover, this led to transportation improvements in eastern Bangkok, including the redevelopment of Sukhumvit and Rama IV Roads, and the construction of New Petchaburi Road (The National Radio News, 1959; The National Radio News, 1960). Despite the withdrawal of the US military in 1973, the country was still granted aid from international financial institutions, such as the International Monetary Fund (IMF) and the Asian Development Bank (ADB). Thus, transportation development in Bangkok, such as expressways, overpasses, and mass transit systems, could be carried out afterward (Aran Nongpol, 2017; Bangkok Expressway and Metro, 2019; Siam Archives 2537, 2011: p. 531; Siam Archives 2538, 2011: p. 499). Consequently, this also improved accessibility and boosted business growth in $\mathrm{Pa}$ thumwan District.

Chulalongkorn University was considered the most influential landowner during the 1960s as a result of its pioneering role in business in the Pathumwan District. In 1960, the university developed a 300-rai (119 acres) piece of land on Rama I Road for Siam Square, a recreational and service area for students and 
university officers. The project was originally carried out by the Wang Mai Company. However, because the company failed to complete the project, the construction work was transferred to the Southeast Asia Company (later known as Seacon Company) in 1964. It included 1100 shophouse units, movie theatres, bowling lanes, an ice-skating rink, and hotels. Under the agreement, the company would receive profits from the development for 10 years before returning the commercial project back to the university (Chulalongkorn University, 2017: p. 68; Thai National Archives, 1970).

Since Siam Square became one of the most significant commercial areas in the district, the landscape around the university, which was originally orchards and squatter lands, was rapidly transformed via the construction of several retail shops and office buildings. In addition, the university built another 20-million-baht commercial project along Banthat Thong and Rama IV Roads in 1970, and the project was operated by the Southeast Asian Company. Similar to Siam Square, the company was allowed to earn profits from the project for 15 years after the completion of construction. Between 1965 and 1970, the university also planned to redevelop Sam Yan Market near Banthat Thong and Rama IV Roads, and Charoenpol Market and the surrounding area of the National Stadium to be a mixed commercial-residential zone (Chulalongkorn University, 2017: pp. 93-99; Thai National Archives, 1966-1970; Thai National Archives, 1970).

By 1978, the university also planned to develop a new commercial project, which was later known as Maboonkrong Shopping Center (MBK). Therefore, a 23-rai (9.10 acres) plot of land at Pathumwan Intersection, formerly the location of student dormitories and several rental shophouses, was chosen for constructing the project. After dealing with financial difficulty in construction management for several years, this commercial complex was finally opened in 1985. It included an 8-story shopping mall, a 20-story office tower, a 29-story hotel (Pathumwan Princess Hotel), and a convention hall, with the total area of all the buildings at 140,000 sq.m. (Chulalongkorn University, 2017: pp. 114-115; "Maboonkrong Center Nakorn Hin-on Pua Sappa Turakit [The Marble Business City, Maboonkrong Center]”, 1983: p. 12; MBK, 2019; Siam Archives 2521, 2011: p. 756).

Moreover, by 1984, Siam Square Tower was constructed on the site of the old bowling lanes to provide more commercial rental spaces. However, the building was later rented to the Accor Group to be redeveloped as the 429-room Novotel Hotel ("Card Chern Bab Mai [The New Invitation Card]", 1989: p. 22; Torsuwan, 2010: p. 175). In order to manage properties efficiently, in 1996, the university hired Bovis Development to create a commercial master plan for their property (Chulalongkorn University, 2017: p. 89).

Besides Chulalongkorn University, the $\mathrm{CPB}$ held the shares of businesses located in the Pathumwan District, such as the Dusit Thani Hotel, and the Siam Intercontinental Hotel (Ouyyanont, 2015: p. 20). By 1973, the CPB also started to develop its own commercial project on the opposite side of Siam Square in the 
vicinity of Srapathum Palace. It consisted of a 6-story department store and a 40 -story office tower, and it was considered the tallest commercial building in Pathumwan District. This commercial project was operated by Siam Piwat Company, the real estate company that was owned by the CPB itself. ("Picharana Wang Krongsrang Thanon Loifa Nai Pranakorn [Consideration of Overpass Construction in the City]", 1971: p.21; Siam Piwat, 2019).

Aside from the real estate development in the area of Srapathum Palace, the $\mathrm{CPB}$ also had to deal with the property issue of the Petchabun Palace, a large plot of land at the Ratchaprasong Intersection. By 1962, the palace was transferred to Prince Varanond, the heir of Prince Chudadhuj Dharadilok, the original owner of Petchabun Palace. The property was considered the most valuable asset that the Petchabun House owned, which cost 200 million baht. This plot was later mortgaged in 1967 to operate an airline owned by the Phetchabun Family. Then, the property was bought back by the CPB (Thai National Archives, 1967), and it was developed in 1987 as another commercial project-the World Trade Center. The project was initially carried out by the Techapaibul Group, which won the property auction for 10,000 million baht in 1983. The proposal included a 6-story shopping mall, a 63-story office building and another hotel building in the same area ("Prakard Dernna World Trade Center Yan Tun Prom Long Saokhem Maysa Ni [Construction Preparation of World Trade Center in this April]", 1987: p. 17; Siam Archives 2529, 2011: pp. 372-373; "World Trade Center Moradok Athan Khong Wirun Thechapaibun [The Curse of World Trade Center]", 1987: p. 17). However, because of the economic crisis in 1997, the construction process was delayed, and the project was later taken over by the Central Pattana Group (CPN) in 2001 ("Awasarn World Trade Center [The End of the World Trade Center]", 2003: p. 22-23).

Because of commercial development on the large plots of land belonging to Chulalongkorn University and the $\mathrm{CPB}$, more commercial development projects emerged along the major roads in the district. These included, for example, the Phloenchit Arcade, the Ratchadamri Arcade, the Chalermlok Shopping Mall and the Central Department Store at Ratchaprasong. These shopping malls included different types of amenities, such as retail shops, restaurants, movie theatres, and theme parks (Anusorn Praratchathan Ploengsob Nai Thaweesak Chantaravirot [Memorial of Mr. Thaweesak Chantaravirot], 1977: p. 12; "Central Department Store, Wang Burapa”, 1972: p. 1, 16; "Ratchadamri Arcade”, 1971: p. 14). Aside from the two major landlords, Amarin Development was another influential real estate developer in Pathumwan District. The company owned Amarin Plaza, which opened in 1986 on another corner of Ratchaprasong Intersection, and also took over the Erawan Hotel, which was located next to the Amarin Plaza, from Saha Rongram Thai, a public agency, after its huge business deficit in 1985 (Siam Archives 2530, 2011: p. 133). Thus, the hotel was redeveloped and became a part of the Hyatt hotel chain. This redeveloped hotel had 400 rooms, a 1500-seat conference hall, and a 5-story shopping mall ("Rongram Erawan Tee Kamlung 
Ja Plean Pai [Changing Erawan Hotel]", 1988: pp. 61-64; The Erawan Hotel, 2019).

\subsubsection{Business Booming since the 2000s by the Development of Mass-Transit Systems in Bangkok}

Although the real estate industry suffered a steep decline due to the economic crisis in 1997, the development of mass-transit systems in Bangkok during the 1990s created an impact on commercial development in Pathumwan District. There were three mass-transit service routes available in the district: BTS Sukhumvit Line, BTS Silom Line, and MRT Blue Line. BTS Sukhumvit and Silom Lines were known as the BTS Skytrain. Both routes opened in 1999, and run along Rama I, Phloenchit, Sukhumvit, Ratchadamri, Sathorn, and Silom Roads. Moreover, Siam Station was designed to be an interchange station between the two lines. The Skytrain was operated by the Bangkok Metro Public Company Limited (BMCL), one of the companies under the Thanayong Group (Bangkok Mass Transit System Public Company Limited, 2018; Siam Archives 2541, 2011: p. 1408). Meanwhile, the Blue Line has been in service since 2004 and is operated by the Mass Rapid Transit Authority of Thailand (MRT), a public organization. It is located underground along Rama IV, Ratchadapisek, Ladphrao and Pahonyothin Roads (Siam Archives 2541, 2011: p. 1301; Siam Archives 2542, 2011 : pp. 911-912, 1329-1330).

Because of its properties situated next to all three mass-transit routes, as well as the overall Thai economy recovering from the recession in 2003, Chulalongkorn University received huge business benefits. Thus, the university redeveloped all of its existing commercial areas, and also gentrified the areas rented by local communities and minor business owners. Moreover, the university had already hired Bovis Development in 1996 to draw up a commercial master plan for the future development of their properties. Thereafter, the master plan was revised three times between 2008 and 2016 (Chulalongkorn University, 2017: pp. 89-100).

By 1998, Center Point of Siam Square was developed by Pon Pailin Development in order to restore sluggish commercial activities in Siam Square after the 1997 economic crisis. The project was located on the 1-rai (0.40 acres) parking area located between Soi 3 and Soi 4 in Siam Square. It was intended to be a gathering spot for young people. Besides the plaza with multimedia systems for holding several outdoor events, the area also provided small retail rental units. The project became a huge success because of its location close to the Siam Station of the BTS Skytrain ("36 Pi Siam Square Shopping Center Bab Thai [36 Years of Siam Square, Thai Shopping Center]", 2002: pp. 165-168; "Central Point Plickchom Shopping Center Sue Media Center [Central Point Became Media Center]", 2004: pp. 76-78). After the contract with the developer ended in 2010 , this active gathering spot was replaced by a new commercial project, the Digital Gateway, which was developed by the Thai Charoen Cooperation to be a gathering space with multiple stories for more rental spaces (Chulalongkorn University, 2017: pp. 105-106). 
Since 2004, the university has raised the monthly rent of Siam Square to 80,000 - 160,000 baht/unit as a result of its close location to the mass transit stations: Siam and Sam Yan Stations. Thus, several tenants complained while the university insisted that the rental rates were in fact lower than the actual rent by $50 \%-60 \%$. The university also shortened the rental period of any contract to 5 10 years to avoid subleasing. Additionally, these changes caused intense competition among former and new businesses in the commercial area (Siam Archives 2547, 2011: pp. 2074-2075).

By 2008, Chamchuri Square was constructed on a 20-rai ( 8 acres) plot of land at the intersection of Rama IV and Phayathai Roads. The complex contains a 42 -story office building, a 26-story condominium, an education center, and it connects underground to the Sam Yan MRT Station. The project was originally developed in 1992 by the JAIDO Group, and it was then called the CU Hi-tech Square. However, the construction process struggled because of financial difficulties between 1992 and 2002. In 2004, the construction work was transferred to new companies, and it was completed in 2008 (Chulalongkorn University, 2017: pp. 126-135).

Furthermore, more commercial projects emerged due to revisions of the master plan. Examples are the redevelopment of Sam Yan that included Suan Lung Square and Zy Walk at Chula Soi 5, I'm Park at Chula Soi 22, the Stadium One next to the National Stadium, the New Sam Yan Market, as well as several residential buildings (Chulalongkorn University, 2017: pp. 90-100). Additionally, because of the damage in the commercial area caused by the political protest in 2010, there were gentrified projects in Siam Square, such as Siam Kitti Building, Digital Gateway, and Siam Square One (Chulalongkorn University, 2017: pp. 136-142; Siam Archives 2553, 2011: pp. 642, 2986).

The CPB also benefited from the mass transit development in Pathumwan District. The organization signed contracts with two major real estate developers: The Mall Group and Central Pattana (CPN). The Mall Group was responsible for redeveloping the property of the Siam Continental Hotel to be a luxurious shopping mall, Siam Paragon. Meanwhile, the Mall Group collaborated with Siam Piwat to construct Siam Discovery situated next to the Siam Center and Siam BTS Skytrain Station ("Ring of Fire", 2014: pp. 151-172; Sintuwathin, 2005: pp. 164-168). This also benefited the Emporium, another shopping mall of the Mall Group that was built in another prime location adjacent to Prompong BTS Skytrain Station. To occupy the areas on both sides of the Prompong Station, the Mall Group constructed the Emquartier, another shopping mall on the opposite side of the Emporium (Jitpleecheep, 2013; Jitpleecheep, 2014; Maikaew, 2014).

By 2001, the CPN Group took over the business of the World Trade Center at Ratchaprasong Intersection from the Chapaibul Group, which became insolvent due to the economic recession in 1997. The project was rebranded as the Central World Plaza, and its construction was completed in 2007. As with the previous 
business scheme, it was structured as a commercial complex that included shopping malls, hotels and office spaces ("Awasarn World Trade Center [The End of the World Trade Center]”, 2003: pp. 22-23; Siam Archives 2551, 2011: p. 1386; "World Trade Center Tamnan Tee Yao Nan Jon Lomleaw [The Story of the World Trade Center]", 2001: pp. 60-72).

After the success of the Central World Plaza, in 2005, CPN purchased a plot of the British Embassy on Wittayu Road to develop another luxurious shopping mall, the Central Embassy ("Sathantud Angrit Tadjai Khai Teedin Plang Ngam Kamrai Kwa 1.6 Panlan Klabnork [British Embassy Sold its property for 1.6 Thousand Million Baht]", 2005: p. 8; Sukthid, 2006: pp. 48-52). The CPN also had to rent another CPB plot that was located next to the embassy in order to have sufficient construction space for the project (Siam Archives, 2553 2011: p. 561). Finally, in 2018, the CPN bought the last piece of the plot of the British Embassy to develop another commercial project. As a result, the British Embassy buildings were completely demolished in 2019. Together with the Central Chidlom, the CPN's department store constructed in 1973 close to the British Embassy, this business group started to occupy most of the commercial area of Ratchaprasong Intersection.

From the above explanation about the two cycles of commercial development, it is apparent that the business potential of the first cycle was generated through the road network development. Therefore, Chulalongkorn University initiated commercial development of its properties, which also spurred the CPB and other business groups to start the investment projects. Thus, commercial buildings emerged along the road network, affecting the transformation of the urban landscape in the district. After the construction of the mass-transit systems, which contributed to the robust flow of people along the BTS Skytrain route, commercial development of Pathumwan District in the second cycle thrived and grew enormously.

\subsection{Business Status as Quasi-Public Agencies}

As quasi-public agencies, both Chulalongkorn University and the $\mathrm{CPB}$ are defined as juristic entities and are also self-governing organizations. Responsible for providing public services or protecting important treasures of the nation, the agencies are also allowed to conduct business from the properties that they own. Because the agencies are partly involved in public affairs, they are waived from paying taxes on their earned income. Despite several objections to the privileges of the organizations, Chulalongkorn University and the CPB have been able to gain more autonomy in their financial management. The ambiguous status and the advantages of both organizations can be explained as follows.

Although Chulalongkorn University has been a juristic bureau with full authorization over its properties since 1939, the discussion regarding the propriety of the university using its properties for commercial purposes was still raised, owning to the noticeable emergence of several large commercial projects and the 
large number of evictions from the university's properties since the 1960s ("Ban Jadsan [housing estate]", 1973: p. 4; Thai National Archives, 1970). By the 1980s, there was also opposition to the construction of the MBK at Pathumwan Intersection from Chulalongkorn students, the tenants of the university, and the Bangkok Authority. The project was planned to be built on the area of the old student dormitories and some rental plots. Thus, this was criticized by the public regarding the role of the university in running the business. Moreover, it was believed that the project would cause more traffic congestion in the area (op. cit. 1966).

Despite criticism about the role of the institution, the university continued to transform the surrounding areas of the campus into commercial zones. Moreover, in order to manage these non-educational properties effectively, the Property Management of Chulalongkorn University (PMCU) was established as a separate unit directly under the university president. By 1979, the new Chulalongkorn University Act was adopted, giving the university full authorization to manage its properties and exempting it from having to report any of the institution's income to the Ministry of Finance. Consequently, these new conditions generated more privilege for the university to conduct uncontrolled real estate development (Chulalongkorn University, 2017: pp. 71-71; Torsuwan, 2010: p. 195; Thai National Archives, 1966).

However, between 1984 and 1985, there was a conflict between the university and the Treasury Department regarding the ownership of the university estate covering areas along Henri Dunant, Rama I, Banthat Thong, and Rama IV Roads. According to Treasury Department Regulation 2518 BE (1975 AD), all universities in the country were considered public properties and had to transfer their properties to the department. Moreover, all transferred properties were only allowed to be used for educational purposes (Siam Archives 2528, 2011: pp. 383-385; "Suk Pipat Teedin Chula Polprayod Nuea Kwam Tooktong [Conflict over Chulalongkorn's Properties is All about Profit]", 1984: pp. 8-10).

Nevertheless, Chulalongkorn University declined to transfer the properties to the department based on the justification that its properties were given to it by King Rama VI, and the university argued that its estates were neither considered public land nor owned by the Treasury Department. Moreover, the university claimed that the government already approved the conveyance of the estates of Chulalongkorn Hospital to the Thai Red Cross Society from the university in 1979 without any concerns over its property possession rights, and this would also follow King Rama VI's intention to use the plots in providing financial support for education ("Teedin Chula Kwam Khatyang Pue Polprayot Khong Krai [Conflict over Chula's Properties]", 1985: pp. 75-76; “Teedin Ratchapatsadu Kab Chula Polprayot Nuea Kodmai [A Conflict between the Treasury Department and Chulalongkorn University is beyond Legality]", 1984: pp. 4-5).

In the case of the $\mathrm{CPB}$, the agency became a juristic entity in 1948. Thus, the bureau was changed from a public agency to a business and was not subject to 
public scrutiny. Although the CPB already made some investments in commercial projects in the 1960s, real estate development was not yet considered a major source of income of the CPB. The bureau's income was mainly earned from business shares, such as those in Siam Commercial Bank, Siam Cement Company, and Deves Insurance. During the 1970s, the bureau held shares in more than 30 businesses including the real estate projects in Pathumwan District such as the Siam Intercontinental, the Dusit Thani Hotel, and the World Trade Center (Ouyyanont, 2015, pp. 20-21; "Raingan Piset Samnakngan Sabsin [Special Report of the Crown Property Bureau]", 1987: pp. 130-147).

Later, the CPB gradually became intensively involved in commercial projects in Pathumwan District. Especially since 2001, to solve problems arising from the 1997 economic crisis, the bureau aimed to enhance its businesses at the international level through joint ventures with foreign investors, and to expand its market beyond the domestic level (Ouyyanont, 2015: pp. 29-31). Moreover, the $\mathrm{CPB}$ made business contracts with other private developers, such as the CPN and the Mall Group, in order to develop its plots of land in Pathumwan District and beyond.

As a quasi-public agency, the $\mathrm{CPB}$ received support from public agencies when the bureau faced any conflicts with local communities. The CPB chose to compromise with them rather than enforce eviction. For example, in 1980, the CPB developed a real estate project on Rama IV Road as a mixed commercial-residential complex, and this project also involved community relocation, which took nine years of negotiations between representatives of different groups, namely an NGO representing the community, the CPB, the Bangkok Metropolitan Authority (BMA) invited as a mediator, and Saha Krungthep Pattana, the contractor of the project, to resolve. An agreement was finally reached in 1989, and the community was relocated to a nearby area (Siam Archives 2523, 2011: p. 779; Siam Archives 2524, 2011: p. 817; Siam Archives 2532, 2011: p. 649).

However, there was later a significant change in the status of the CPB as a quasi-public agency. Between 2017 and 2018, the Crown Property Bureau Act was revised in order to change the status of the organization to that of a royal private agency. All royal properties became private ones. In addition, the revision gave the King full authority to choose all committee board members, and the agency was now required to pay taxes annually (Praratchabanyad Chadrabieb Sabsin Fai Pramaha Kasat 2560 [The Royal Property Management Act 2560], 2017; Praratchabanyad Chadrabieb Sabsin Pramaha Kasat 2561 [The King's Property Management Act 2561], 2018). This new act would affect the organization's business strategy in Siam Square, Ratchaprasong Intersection, and its commercial development projects in the future.

\subsection{Commercial Clusters as Urban Spatial Pattern in Pathumwan District}

As a result of transportation development and the growth of commercial busi- 
nesses over time, Pathumwan District became a prominent commercial zone. As the owners who possessed most of the land in the district, Chulalongkorn University and the $\mathrm{CPB}$ also gained huge benefits from developing their properties to be commercial spaces. While Chulalongkorn University aimed to construct buildings and spaces for rent, the CPB granted concessions to private investors to develop commercial projects through Siam Piwat Company, a leading world-class retail and real estate developer, as its own business representative. Business actors, such as the Mall Group and the CPN, took a crucial part in the commercial development of the district. In addition to the estates of the CPB, these developers also tried to occupy plots of land around the mass transit stations in order to connect these plots with those of the CPB. Consequently, this generated a commercial cluster of each business group along the transit corridor (Figure 4).

Aside from the Mall Group that dominated commercial spaces around Siam and Prompong Stations through the development of Siam Paragon and the Em District, the CPN took over spaces around Chidlom Station at Ratchaprasong Intersection by combining commercial projects, i.e., Central World Plaza, Central Chidlom, and the Central Embassy. Chulalongkorn University possessed areas around the National Stadium, Siam, and Sam Yan Stations. Additionally, the Amarin Group, one of the influential real estate developers in Ratchaprasong Intersection, could sustain its businesses (Amarin Plaza and Erawan Hotel) by collaborating with Gaysorn Property, the owner of the Gaysorn Plaza on another side of the intersection ("Ring of Fire", 2014: pp. 158-169; Sintuwathin, 2005: pp. 148-222). Nevertheless, there were also several minor business owners dispossessed from the areas as a result of their inability to maintain their businesses amid the intense commercial competition.

As a result of the formation of the commercial clusters along the mass transit routes, the whole district gradually turned into an absolutely luxurious commercial space that attracts high- and middle-income customers. Furthermore, the Skywalk, an elevated walking path that links the stations to proximate buildings, was considered a crucial urban element that encourages the formation of the commercial clusters. The structure was built to improve the pedestrian flow between the stations and the commercial buildings, and also created another layer of urban space above regular footpaths on the ground level ("Upgrade for Elevated Pedestrian-Bike Lane”, 2013). Moreover, this spurred development of optional transportation routes in order to improve the connection between the stations and other areas. For example, by 2013, the BMA had developed a walking path and bike lane along the Saen Saep Canal ("Admin court orders BMA to build walkway along Saen Saep Canal", 2013; Jikkham, 2012).

As a result of the concentration of these commercial clusters, Pathumwan District became a popular location for holding several national and international events, including the Bangkok Film Festival and the Bangkok Fashion City Extravaganza. The Bangkok Film Festival was a big Southeast Asian event held 


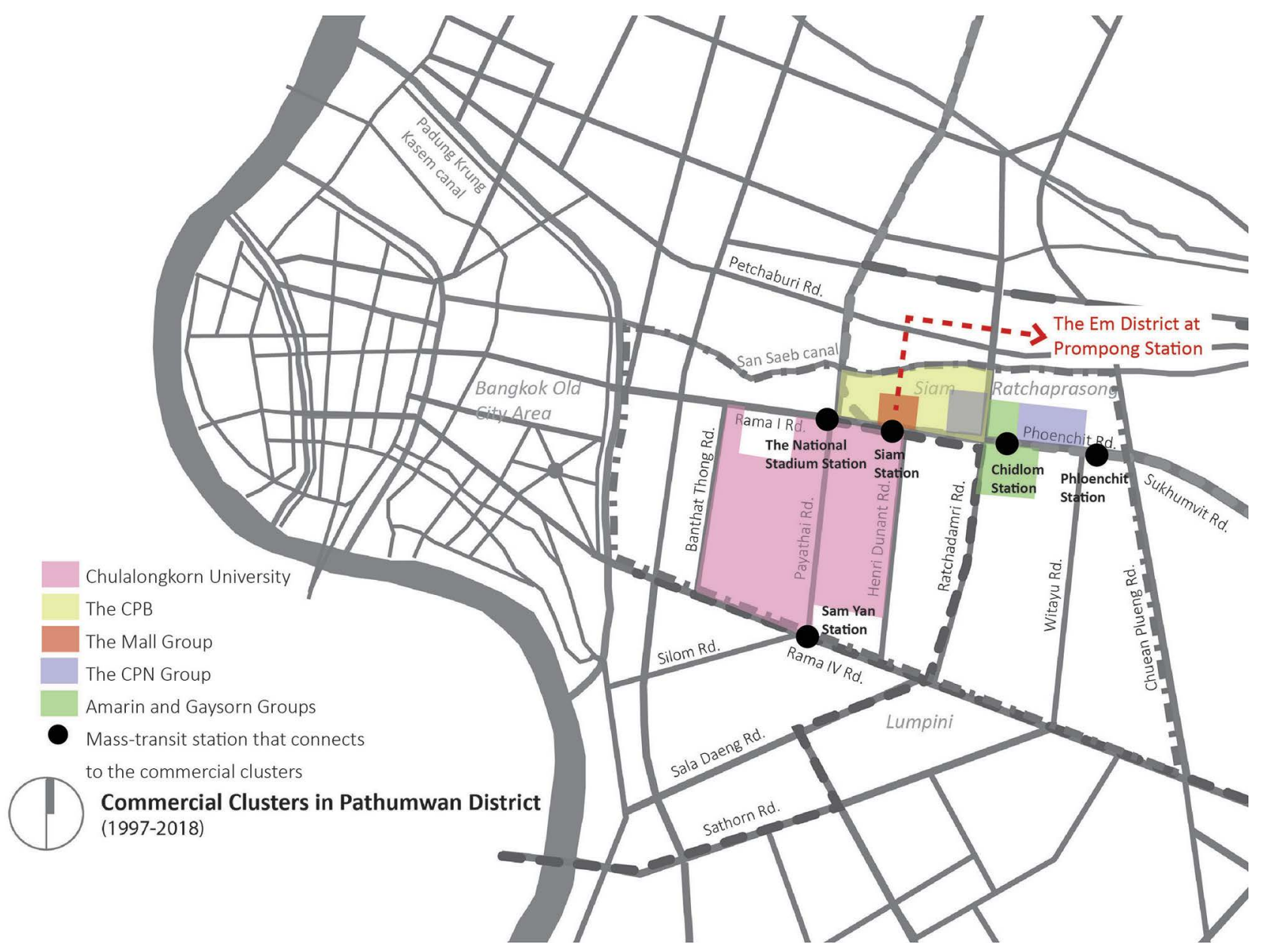

Figure 4. The commercial clusters in pathumwan district (created by the authors).

every year from 2003 to 2006 at theatres near the Siam Station (Siam Archives 2546, 2011: pp. 40-41; Siam Archives 2548, 2011: p. 7), and the Bangkok Fashion City Extravaganza was held in February 2004. The festival took place at multiple locations inside the commercial clusters: Siam Discovery, Siam Center, Siam Paragon, and the Emporium. Moreover, through the collaboration of the developers, landlords and the Bangkok Metropolitan Authority (BMA), a fashion parade was arranged as the highlight of the festival. It stretched along Rama I, Phloenchit and Sukhumvit Roads from the National Stadium to the Emporium ("Bangkok Fashion City Extravaganza 2004", 2004: p. 36; Siam Archives 2547, 2011: pp. 210, 300-301, 329).

In addition to being a venue for promoting different types of businesses, the area around the mass transit station in a given district also became a political gathering space. By 2010, a huge demonstration of the Red Shirt protesters, mostly from the labor class in Thailand, was staged at Ratchaprasong Intersection, which was considered an area of the middle class and high-income people in Bangkok. As a consequence of the uncontrollable violence of the situation, commercial buildings around Siam Station and a part of the Central World Plaza 
at Ratchaprasong Intersection were burned down (Siam Archives 2553, 2011: p. 642, 2986). Apart from commercial buildings in the district, the Bangkok Art and Cultural Center (BACC) of the BMA, the first art museum in Bangkok, opened in 2008 as a venue for holding art and cultural events, while an area in front of the BACC occasionally served as a gathering space for young people to demonstrate their political viewpoints ("Kwa Jatung Wanni Khong Hosinlapa Krungthep [Before Becoming Bangkok Art Museum]”, 2008: pp. 110-119; Siam Archives 2544, 2011: p. 1212).

\section{Conclusion of the Study}

The study of the urban spatial pattern of the Pathumwan District reveals the existence of royal influence over the development of urban spaces in Bangkok after the end of the absolute monarchy period. Part of the royal authority over their public properties in Pathumwan District, including buildings and plots of land, was transferred to quasi-public agencies, that is, the Crown Property Bureau and Chulalongkorn University. These quasi-public agencies were originally established in order to manage all royal public properties for the public benefit. However, the agencies later became influential business actors in the district as a result of road network development and mass-transit construction over time. Both agencies were juristic persons independent of government control. Because of their full authority in making business decisions on the large plots of land in the district, Pathumwan became a new commercial zone of Bangkok, and has remained one, since the 1970 s.

Apart from commercial development projects on royal plots of land belonging to the two agencies, there were also private business development projects in the nearby areas. Additionally, the CPB attracted prominent real estate developers, namely the CPN and the Mall Group, to forge business partnerships with the agency. Both developers later purchased more plots of land to expand their businesses. Meanwhile, former less competitive businesses were replaced by these new larger commercial projects. Consequently, these generated commercial clusters along the transportation corridors in Pathumwan and the nearby districts.

It is noteworthy, however, that the commercial clusters in Pathumwan District are not directly occupied by foreign managerial elites through the information network system. The business spaces in the clusters are operated by the quasi-public agencies with business advantages from a privileged background as royal entities. Each cluster is connected via the networks of transportation systems while the inside rental spaces are provided to several global business firms. Finally, the emergence of these commercial clusters can be considered the specific urban spatial pattern of the Pathumwan District after the end of the period of Thai absolute monarchy. Moreover, the formation of the clusters reflects the ability of the Thai royal family to adapt to the new socio-economic context that is influenced by the global economy. 


\section{Conflicts of Interest}

The authors declare no conflicts of interest regarding the publication of this paper.

\section{References}

\section{Books and Journals}

Anusorn Praratchathan Ploengsob Nai Thaweesak Chantaravirot [Memorial of Mr. Thaweesak Chantaravirot] (1977). Anusorn Praratchathan Ploengsob Nai Thaweesak Chantaravirot [Memorial of Mr. Thaweesak Chantaravirot]. Bangkok.

Askew, M. (2002). Bangkok: Place, Practice and Representation. New York: Routledge.

Baker, C., \& Phongpaichit, P. (2005). A History of Thailand. Melbourne: Cambridge University Press.

Bunnag, P. (1982). Canals in Bangkok: History, Changes, and Their Impact (1782 A.D.-1982 A.D.). Bangkok: Chulalongkorn University.

Douglass, M. (2001). Urban and Regional Policy after the Era of Naïve Globalism. In A. Kumssa, \& T. G. McGee (Eds.), New Regional Development Paradigms (Vol. 1, Ch. 3, pp. 33-56). Westport, CT: Greenwood Press.

Evers, H.-D., \& Korff, R. (2000). Southeast Asian Urbanism: The Meaning and Power of Social Space. New York: St. Martin's Press.

Jackson, P. A. (2010). Afterward: Postcolonial Theories and Thai Semicolonial Hybridity. In R. V. Harrison, \& P. A. Jackson (Eds.), The Ambiguous Allure of the West: Trace of the Colonial in Thailand (Ch. 9, pp. 187-206). Hong Kong: Hong Kong University Press. https://doi.org/10.5790/hongkong/9789622091214.003.0010

King, R. (2011). Reading Bangkok. Singapore: NUS Press.

McGee, T. G. (1967). The Southeast Asian City: Social Geography of Primate Cities of Southeast Asia. London: G. Bell \& Sons.

McGee, T. G., \& Robinson, I. M. (1995). ASEAN Mega-Urbanization: A Synthesis. In T. G. McGee, \& I. M. Robinson (Eds.), The Mega-Urban Regions of Southeast Asia (pp. 343-355). Vancouver: UBC Press.

O’Connor, R. A. (1983). A Theory of Indigenous Southeast Asian Urbanism. Singapore: Institute of Southeast Asian Studies. https://doi.org/10.1355/9789814376174

Ouyyanont, P. (2015). Crown Property Bureau in Thailand and Its Role in Political Economy. Singapore: Institute of Southeast Asian Studies.

https://doi.org/10.1355/9789814695169

Pathumwanaram Temple (1977). Prawat Wat Pathumwanaram [History of Pathumwanaram TempleJ. Bangkok.

Preyawanit, N. (2017). Setthakit Karnmueng Khong Karn Tad Thanon Nai Pranakorn [Political Economy of Road Construction in the Capital City]. Bangkok: ET Publishing.

Sritulpan, S. (1957, 2006). Chomna Sakdina Thai [Thai Feudalism]. Bangkok: Nitisat Chabab Satawat Mai. Reprint, Bangkok: Vision Prepress.

Tantivess, N. (2020). Studying the Transformation of Bangkok, Thailand, through Urban Representations of the Sukhumvit Corridor. Doctoral Dissertation, Cincinnati, OH: School of Planning, University of Cincinnati.

Torsuwan, P. (2010). Karnmuang Ruang Siam Square [Politics of Siam Square]. Bangkok: Laisen Publishing. 


\section{Public Documents}

Thai House of Representatives (1936). Thai House of Representatives. Meeting Record, March 29.

Announcement of the Office of the Prime Minister about the Appointment of the Crown Property Bureau's Committee (1937a). Announcement of the Office of the Prime Minister about the Appointment of the Crown Property Bureau's Committee. Thai Government Gazette, Vol. 59, July 19, 739.

Announcement of the Office of the Prime Minister about the Appointment of the Crown Property Bureau's Committee (1937b). Announcement of the Office of the Prime Minister about the Appointment of the Crown Property Bureau's Committee. Thai Government Gazette, Vol. 61, sec. 63, October 10.

Praratchabanyad Chadrabieb Sabsin Fai Pramaha Kasat 2560 [The Royal Property Management Act 2560] (2017). Praratchabanyad Chadrabieb Sabsin Fai Pramaha Kasat 2560 [The Royal Property Management Act 2560]. Thai Government Gazette, Vol. 134, sec 75 ก. July 16.

Praratchabanyad Chadrabieb Sabsin Pramaha Kasat 2561 [The King's Property Management Act 2561] (2018). Praratchabanyad Chadrabieb Sabsin Pramaha Kasat 2561 [The King's Property Management Act 2561]. Thai Government Gazette, Vol. 135, sec 88 ก. November 3.

Bangkok Municipal Ministry (1897). Rai Ngan Raka Khaopleuk Tambol Saen Seap [Reporting the Prices of Unmilled Rice in San Seap Sub-District] (pp. 2-5). Reel no. ม-ร.5น/650, sub no. น.41.1/58, Thai National Archives. Microfilm.

Bangkok Municipal Ministry (1902-1903). Thanon Lae Lumkhlong [Roads and Canals]. Reel no. ม-ร.5น.92, sub no. น.5.8/49, Thai National Archives. Microfilm.

Bangkok Municipal Ministry (1907a). Prubprung Khlong Saen Seap [Improving Saen Seap Canal] (pp. 192-193). Reel no. ม-ร.5น/e, sub no. 41.1/192-193, Thai National Archives. Microfilm.

Bangkok Municipal Ministry (1907b). Kid Ja Srang Torasub Tam Huamueng Monton Krungthep [Constructing Telephone System in Neighboring Provinces of Bangkok] (pp. pp. 2-22). Reel no. ม-ร.5น/200, sub no. 16/30, Thai National Archives. Microfilm.

Bangkok Municipal Ministry (1911). Mai Kamnodkarn Somdet Prapanpi Luang Ja Sadet Prapas Huamueng Jangwad Samutprakarn [Traveling Schedule of the Queen Mother to Samutprakarn] (pp. 9-16). Reel no. ม-ร.6น/218, sub no. 17/28, Thai National Archives. Microfilm.

Chulalongkorn University (2017). Nhuengroi Pi Karn Borihan Jadkarn Teedin Khet Karnjadkarn Sabsin Chulaongkorn Mahawittayalai [One Hundred Years of Property Management by Chulalongkorn University]. Bangkok: Chulalongkorn University.

Property Alienation Act about Transferring Land in Pathumwan District between Pai Sing to Canal, Ratchadamri and Sanam Ma Roads to the Red Cross Society 1942. Thai Government Gazette, Vol. 59, sec. 61, December 29.

Property Alienation Act about Transferring Land of the Crown Property Bureau to Chulalongkorn University 1939. Thai Government Gazette, Vol. 56, October 30, 1364.

Thai National Archives (1966-1970). Koranee Thucharit Teedin Chula [A Corruption Case of Chalalongkron University]. No. ก-ป2-2513-14-ปึก1, Bangkok: Department of Fine Art.

Thai National Archives (1967). Tee Din Wang Petchabul [The Case of Petchabul Palace]. No. ก-ป7-2510-13, Bangkok: Department of Fine Art.

Thai National Archives (1970). Koranee Teedin Siam Square [The Case of Siam Square]. 
No. ก-ป2-2513-14-ปึก2, Bangkok: Department of Fine Art.

Tourism Division, Culture, Sports and Tourism Department, BMA (2011). Bangkok Bok Lao Rueng [Stories about Bangkok]. Bangkok: Bangkok Metropolitan Administration.

\section{Newspapers and Magazines}

(1871). The Map of Bangkok. Bangkok Calendar, 146-157.

(1971). Picharana Wang Krongsrang Thanon Loifa Nai Pranakorn [Consideration of Overpass Construction in the City]. Prachathipatai, 25 February 1971, 21.

(1971). Ratchadamri Arcade. Siamrat, 9 December 1971, 14.

(1972). Central Department Store, Wang Burapa. Siamrat, 4 November 1972, 1-16.

(1972). Nakonluang Wanprungnee [A City of Tomorrow]. Siamrat, 23 April 1972, 10.

(1973). Ban Jadsan [Housing Estate]. Advertisement, Prachathipatai, 25 August 1973, 4.

(1983). Maboonkrong Center Nakorn Hin-on Pua Sappa Turakit [The Marble Business City, Maboonkrong Center]. Than Setthakit, 18-23 April 1983, 12.

(1984). Suk Pipat Teedin Chula Polprayod Nuea Kwam Tooktong [Conflict over Chulalongkorn's Properties Is All about Profit]. Matichon Sudsabda, 5 February 1984, 8-10.

(1984). Teedin Ratchapatsadu Kab Chula Polprayot Nuea Kodmai [A Conflict between the Treasury Department and Chulalongkorn University Is beyond Legality]. Siamrat Sabdavijarn, 22 April 1984, 4-5.

(1985). Teedin Chula Kwam Khatyang Pue Polprayot Khong Krai [Conflict over Chula's Properties]. Turakit Teedin, May 1985, 75-76.

(1987). Prakard Dernna World Trade Center Yan Tun Prom Long Saokhem Maysa Ni [Construction Preparation of World Trade Center in This April]. Turakit Teedin 4, No. 41, 17.

(1987). Raingan Piset Samnakngan Sabsin [Special Report of the Crown Property Bureau]. The Manager, March 1987, 130-147.

(1987). World Trade Center Moradok Athan Khong Wirun Thechapaibun [The Curse of World Trade Center]. Turakit Teedin 4, No. 7, 17.

(1988). Rongram Erawan Tee Kamlung Ja Plean Pai [Changing Erawan Hotel]. Turakit Teedin 5, No. 1, 61-64.

(1989). Card Chern Bab Mai [The New Invitation Card]. Krungthep, 30 August 1989, 22.

(2001). World Trade Center Tamnan Tee Yao Nan Jon Lomleaw [The Story of the World Trade Center]. Dokbiea, July 2001, 60-72.

(2002). 36 Pi Siam Square Shopping Center Bab Thai [36 Years of Siam Square, Thai Shopping Center]. The Manager, February 2002, 165-168.

(2003). Awasarn World Trade Center [The End of the World Trade Center]. Matichon Sudsabda, 3-9 January 2003, 22-23.

(2004). Bangkok Fashion City Extravaganza 2004. Brand Age, March 2004, 36.

(2004). Central Point Plickchom Shopping Center Sue Media Center [Central Point Became Media Center]. Brand Age, January 2004, 76-78.

(2005). Sathantud Angrit Tadjai Khai Teedin Plang Ngam Kamrai Kwa 1.6 Panlan Klabnork [British Embassy Sold Its Property for 1.6 Thousand Million Baht]. Thansetthakit, 20-22 October 2005, 8.

(2006). Thanothai Sukthid. "Pandin Thong Tee Maichai Khong Thai: Sathantud Angrit" [Golden Land Plot Did Not Belong to Thailand: The British Embassy]. Art \& Cultural Magazine, July 2006, 48-52. 
(2008). Kwa Jatung Wanni Khong Hosinlapa Krungthep [Before Becoming Bangkok Art Museum]. The Manager, September 2008, 110-119.

(2014). Ring of Fire. Brand Age, September 2014, 151-172.

Bangkok Bank (1973). Sathanakarn Setthakit Thai 2515-2516 [Economic Situation 1972-1973]. Khaopanich, 31 March 1973, 8.

Sintuwathin, W. (2005). Branding the Destination: The Best Place to Shop. Brand Age, September 2005, 148-222.

\section{CDs}

Siam Archives Company (2011). Siam Archives 2521. DVD-ROM.

Siam Archives Company (2011). Siam Archives 2523. DVD-ROM.

Siam Archives Company (2011). Siam Archives 2524. DVD-ROM.

Siam Archives Company (2011). Siam Archives 2528. DVD-ROM.

Siam Archives Company (2011). Siam Archives 2529. DVD-ROM.

Siam Archives Company (2011). Siam Archives 2530. DVD-ROM.

Siam Archives Company (2011). Siam Archives 2532. DVD-ROM.

Siam Archives Company (2011). Siam Archives 2537. DVD-ROM.

Siam Archives Company (2011). Siam Archives 2538. DVD-ROM.

Siam Archives Company (2011). Siam Archives 2541. DVD-ROM.

Siam Archives Company (2011). Siam Archives 2542. DVD-ROM.

Siam Archives Company (2011). Siam Archives 2544. DVD-ROM.

Siam Archives Company (2011). Siam Archives 2546. DVD-ROM.

Siam Archives Company (2011). Siam Archives 2547. DVD-ROM.

Siam Archives Company (2011). Siam Archives 2548. DVD-ROM.

Siam Archives Company (2011). Siam Archives 2551. DVD-ROM.

Siam Archives Company (2011). Siam Archives 2553. DVD-ROM.

\section{Radio Records}

The National Radio News. Khao Pak Chao (Morning News). Aired February 8 (1959).

The National Radio News. Khao Pak Kam (Evening News). Aired June 15 (1960).

\section{Online Sources}

(2013). Upgrade for Elevated Pedestrian-Bike Lane. Bangkok Post, 11 November 2013. https://www.bangkokpost.com/life/social-and-lifestyle/379187/upgrade-for-elevated-pe destrian-bike-lane

Aran Nongpol (2017). Rujak Lavalin Rodfaifah Sai Rake Tee Konkrung Mai Mee Okard Dai Nang [Lavalin, an Unfinished Skytrain Project]. The Standard, 24 July 2017. https://thestandard.co/news-thailand-lavalin-skytrain

Bangkok Expressway and Metro (2019). Krongkarn Thang Piset [Expressway Projects]. https://expressway.bemplc.co.th/ExpresswayProject.aspx

Bangkok Mass Transit System Public Company Limited (2018). The BTS SkyTrain System Operates in 2 Lines with a Total of 35 Stations. https://www.bts.co.th/eng/library/system-structuer.html

Bangkok Post (2013). Admin Court Orders BMA to Build Walkway along Saen Saep Canal. https://www.bangkokpost.com/thailand/politics/337014/bma-ordered-to-build-canal-si 
de-walkway

Jikkham, P. (2012). Restore Canals to End Traffic Hell, BMA Says. Bangkok Post, 3 November 2012.

https://www.bangkokpost.com/news/politics/319325/restore-canal-to-end-traffic-hellbma-says

Jitpleecheep, P. (2013). Mall Group Adds to the Collection. Bangkok Post, 20 November 2013. https://www.bangkokpost.com/business/380717/mall-group-adds-to-collection

Jitpleecheep, P. (2014). Mall Group Banks Big on AEC. Bangkok Post, 7 May 2014. https://www.bangkokpost.com/business/408417/mall-group-banks-big-on-aec

Maikaew, P. (2014). Office Tower Takes Shape. Bangkok Post, 11 March 2014. https://www.bangkokpost.com/business/399209/office-tower-takes-shape

MBK (2019). Turakit Khong Rao [Our Business]. http://www.mbkgroup.co.th/th/business/shopping/mbk-center

Siam Piwat (2019). Business. https://www.siampiwat.com/en/business

The Erawan Hotel (2019). About Erawan. http://www.theerawan.com 